\title{
Studies on the Variation of Human Serum Lipids by Intaking Lentinus Edodes for the Preservation of Health in Rural Areas
}

\author{
Takeo NAKAMURA*, Tamotsu MIYOSHI ${ }^{2 *}$, Masahide IMAKI ${ }^{2 *}$, \\ Yuki YAMADA ${ }^{2 *}$ and Takeshi YOSHIMURA ${ }^{2 *}$
}

\begin{abstract}
For the preservation of health in rural areas, this paper reports on the variation of human serum lipids by intaking lentinus edodes.

Serum lipids levels showed no significant change by intaking lentinus edodes that amounts of 20 , 40 and $60 \mathrm{~g}$ per day each for 5 days. From data of correlationship between serum lipid levels and nutrition intake of experimental diet, it was recognized that high-density-lipoprotein cholesterol level was directly proportional to carbohydrate-fat ratio significantly $(\mathrm{p}<0.02)$, and was inversely proportional to fat intake, fat-protein ratio and carbohydrate-protein ratio significantly $(\mathrm{p}<0.05)$, respectively. Triglycerides level was inversely proportional to protein intake significantly $(p<0.05)$.

These results concluded that the decrease of serum cholesterol level by intaking of lentinus edodes in healthy young men whose serum cholesterol levels were in normal range was not recognized.
\end{abstract}

(1) preservation of health (2) lentinus edodes intake (3) human serum lipids level

\section{INTRODUCTION}

In recent years, nutrition intake tends to be westernized in Japan. Also in rural areas nutrition intake pattern has been changed by degrees. Therefore, the mortality from atherosclerosis is increasing. As the risk factor of atherosclerosis, serum lipids, blood pressure, obesity, cigarette smoking, etc., are named, among which specially reffering to serum lipids a relationship to diet is worth notice. Atherosclerosis is developed in a prolonged period in complicated relations with each other of genetic, aging, environmental and disease factors and it is closely related to diet. It may be possible to prevent atherosclerosis by lowering the level of serum lipids with $\operatorname{diet}^{1}$. It is an essential subject to clarify dietary factors related to improvement of health aiming at the healthy life.

Lentinus edodes is a characteristic food which is produced in rural areas, and it is said that lentinus edodes decrease the level of serum lipids ${ }^{2 \sim 4)}$. There is much report that lentinus edodes or lentisine which is the hypolipidemic substance decrease the levels of serum and liver cholesterol. These reports, however, are almost result from animal experiments. Little work on the effect of lentinus edodes intake on the human serum lipids has been done so $\mathrm{far}^{5)}$.

The purpose of this report is to examine the variation of human serum lipids by intaking lentinus edodes for the preservation of health in rural areas.

\section{MATERIALS AND METHODS}

The experiments were carried using four male postgraduate students as subjects. Their ages and physique are shown in Table 1. Throughout the experimental period, the subjects remained in the air-conditioned metabolic ward and attended to their daily studies. The subjects got up at around 7-8 o' clock every morning and were weighed the body weight after urination and defecation. Experimental diets were served nearly at fixed times. As sup-

* Faculty of Pharmaceutical Sciences, Kinki University

${ }^{2 *}$ Department of Public Health, School of Medicine, The University of Tokushima 
Table 1. Age and Physique of Subjects.

\begin{tabular}{ccccc}
\hline Subject & $\begin{array}{c}\text { Age } \\
(\text { years })\end{array}$ & $\begin{array}{c}\text { Weight } \\
(\mathrm{kg})\end{array}$ & $\begin{array}{c}\text { Height } \\
(\mathrm{cm})\end{array}$ & Rohrer Index* \\
\hline A & 24 & 90.0 & 173.8 & 171.4 \\
B & 24 & 62.0 & 176.6 & 112.6 \\
C & 22 & 64.0 & 158.0 & 162.3 \\
D & 23 & 63.0 & 172.1 & 123.6 \\
\hline \multicolumn{4}{c}{${ }^{*}$ Rohrer Index $=\frac{\text { Weight }}{\text { Height }^{3}} \times 10^{7}$}
\end{tabular}

Table 2. Composition of Basal Diet for Subject B.

\begin{tabular}{lcccc}
\hline Material & $\begin{array}{c}\text { Energy* } \\
(\mathrm{Cal})\end{array}$ & $\begin{array}{c}\text { Protein } \\
(\mathrm{g})\end{array}$ & $\begin{array}{c}\text { Fat } \\
(\mathrm{g})\end{array}$ & $\begin{array}{c}\text { Carbohydrate } \\
(\mathrm{g})\end{array}$ \\
\hline $\begin{array}{l}\text { Polished } \\
\text { rice }\end{array}$ & 1035 & 20.0 & 3.8 & 222.0 \\
$\begin{array}{l}\text { Whole } \\
\text { egg }\end{array}$ & 258 & 20.0 & 18.3 & 1.5 \\
$\begin{array}{l}\text { Cornstarch } \\
\text { Shortening }\end{array}$ & 547 & & & 135.5 \\
Corn oil & 133 & & 25.0 & \\
$\begin{array}{l}\text { Sucrose } \\
\text { Baking }\end{array}$ & 589 & & 15.0 & \\
powder & 5 & & & 152.2 \\
Soy sauce & 2 & 0.3 & & 1.4 \\
\hline Total & 2790 & 40.3 & 62.1 & 512.7 \\
\hline
\end{tabular}

${ }^{*}$ Energy intake per day was calculated as $45 \mathrm{Cal} / \mathrm{kg}$ of body weight.

plemental food, lentinus edodes was taken up.

Throughout the experimental period, energy intake from the experimental diets for the subjects was $45 \mathrm{kcal} / \mathrm{kg}$ of body weight. Table 2 shows the composition of the basal diet as an example (subject B). Vitamines and minerals were supplemented up to the minimum daily requirement for adult by administration of vitamine complexes and mineral mixtures. Furthermore, for maintenance of good bowel movements $5 \mathrm{~g}$ of agar-agar was given. In the supplemented diet period, in addition to the basal diet, dried lentinus edodes was given at 20,40 and $60 \mathrm{~g}$, respectively. Lentinus edodes was soaked in water to be softened and sliced and cooked with sucrose and a small amount of soy sauce.

Blood was collected from basilic vein early in the morning. Serum lipids were measured within the
Table 3. Nutrition Intake in Experimental Diets.

\begin{tabular}{|c|c|c|c|c|c|}
\hline Diet & Subject & $\begin{array}{c}\text { Energy } \\
(\mathrm{Cal})\end{array}$ & $\begin{array}{c}\text { Protein } \\
(\mathrm{g})\end{array}$ & $\begin{array}{l}\text { Fat } \\
(\mathrm{g})\end{array}$ & $\begin{array}{c}\text { Carbohydrate } \\
(\mathrm{g})\end{array}$ \\
\hline & A & 4050 & 40.0 & 103.1 & 737.8 \\
\hline Basal & B & 2790 & 40.0 & 62.1 & 512.7 \\
\hline \multirow[t]{2}{*}{ Diet } & $\mathrm{C}$ & 2880 & 40.0 & 62.1 & 536.0 \\
\hline & D & 2825 & 40.0 & 62.1 & 524.3 \\
\hline \multirow{4}{*}{$\begin{array}{l}\text { Lentinus } \\
\text { Edodes } \\
\text { Diet } \\
(20 \mathrm{~g})\end{array}$} & A & 4128 & 43.7 & 103.4 & 748.3 \\
\hline & $B$ & 2868 & 43.7 & 62.4 & 523.2 \\
\hline & $\mathrm{C}$ & 2958 & 43.7 & 62.4 & 546.5 \\
\hline & $\mathrm{D}$ & 2914 & 43.7 & 62.4 & 534.8 \\
\hline \multirow{4}{*}{$\begin{array}{l}\text { Lentinus } \\
\text { Edodes } \\
\text { Diet } \\
(40 \mathrm{~g})\end{array}$} & A & 4211 & 47.4 & 103.7 & 760.3 \\
\hline & B & 2951 & 47.4 & 62.7 & 535.2 \\
\hline & $\mathrm{C}$ & 3041 & 47.4 & 62.7 & 558.5 \\
\hline & $\mathrm{D}$ & 2996 & 47.4 & 62.7 & 546.8 \\
\hline \multirow{4}{*}{$\begin{array}{l}\text { Lentinus } \\
\text { Edodes } \\
\text { Diet } \\
(60 \mathrm{~g})\end{array}$} & A & 4294 & 51.1 & 104.0 & 772.3 \\
\hline & B & 3034 & 51.1 & 63.0 & 547.2 \\
\hline & $\mathrm{C}$ & 3124 & 51.1 & 63.0 & 570.5 \\
\hline & $\mathrm{D}$ & 2929 & 51.1 & 63.0 & 520.1 \\
\hline
\end{tabular}

day after separation of serum. Total cholesterol (T-chol) was measured by Zurkowski's method ${ }^{6}$, free cholesterol (F-chol) by digitonin method, high density lipoprotein cholesterol (HDL-chol) by phosphotungstate-magnesium chloride method $^{7)}$, triglycerides (TG) by Fletcher's method ${ }^{8)}$ and phospholipids (PL) by Hoelfmayer-Fried's methods ${ }^{9}$.

\section{RESULTS}

Nutrition intake is shown in Table 3. Protein intake was 40.0-51.1g a day, being below the adult' $\mathrm{s}$ minimum daily requirement. It can be said as a comparatively low protein diet. Fat and carbohydrate intakes were high with the subject A, although throughout the experimental period, the intake showed no special variation. Table 4 shows the ratio of each nutrition. Fat-protein ratio indicated 1-2, carbohydrate-fat ratio 7-9 and carbohydrate-protein ratio $10-18$. It was noted that the experimental diets in this study were low in protein and high in carbohydrate.

Variations of T-chol, F-chol and HDL-chol are shown in Fig. 1. When the daily diet was replaced with the basal diet, T-chol decreased by $19 \mathrm{mg} / \mathrm{dl}$ on 
Table 4. Ratio of Each Nutrition in Diets.

\begin{tabular}{lcccc}
\hline Diet & Subject & F-P & C-F & C-P \\
\hline \multirow{3}{*}{ Basal } & $\mathrm{A}$ & 2.58 & 7.14 & 18.41 \\
Diet & $\mathrm{B}$ & 1.55 & 8.23 & 12.78 \\
& $\mathrm{C}$ & 1.55 & 8.61 & 13.36 \\
& $\mathrm{D}$ & 1.55 & 8.42 & 13.07 \\
Lentinus & $\mathrm{A}$ & 2.37 & 7.24 & 17.12 \\
Edodes & $\mathrm{B}$ & 1.43 & 8.39 & 11.97 \\
Diet & $\mathrm{C}$ & 1.43 & 8.76 & 12.51 \\
(20g) & $\mathrm{D}$ & 1.43 & 8.57 & 12.24 \\
\hline & $\mathrm{A}$ & 2.19 & 7.33 & 16.04 \\
Lentinus & $\mathrm{B}$ & 1.32 & 8.54 & 11.29 \\
Edodes & $\mathrm{C}$ & 1.32 & 8.91 & 11.78 \\
Diet & $\mathrm{D}$ & 1.32 & 8.72 & 11.54 \\
(40g) & $\mathrm{A}$ & 2.04 & 7.43 & 15.11 \\
\hline & $\mathrm{B}$ & 1.23 & 8.69 & 10.71 \\
Lentinus & $\mathrm{C}$ & 1.23 & 9.06 & 11.16 \\
Edodes & $\mathrm{D}$ & 1.23 & 8.26 & 10.18 \\
Diet & (60g) & & & \\
\hline
\end{tabular}

F-P : Fat-Protein ratio,

C-F : Carbohydrate-Fat ratio,

C-P : Carbohydrate-Protein ratio.

an average. By adding $20 \mathrm{~g}$ of lentinus edodes to the basal diet, it increased by $28 \mathrm{mg} / \mathrm{dl}$ on an average, which however remained on nearly the same level even raising the supplemental level of lentinus edodes to $40 \mathrm{~g}$ and $60 \mathrm{~g}$, respectively. The level of $\mathrm{F}$ -chol remained nearly unchanged when the daily diet was replaced with the basal diet. By adding $20 \mathrm{~g}$ of lentinus edodes, it increased by $5.3 \mathrm{mg} / \mathrm{dl}$ on an average, but even when the supplemental level was raised to $40 \mathrm{~g}$ and $60 \mathrm{~g}$, respectively, nearly the same level was maintained. The level of HDL-chol hardly changed even if the daily diet was replaced with the basal diet. By adding $20 \mathrm{~g}$ of lentinus edodes, it decreased by $6.5 \mathrm{mg} / \mathrm{dl}$, but on the contrary an addition of $40 \mathrm{~g}$ increased by $6.8 \mathrm{mg} / \mathrm{dl}$ on an average. Even raising to $60 \mathrm{~g}$, it remained the same level. Throughout the experimental period, no significant variation was observed in the levels of T-chol, F-chol and HDL-chol.

Variations of TG and PL are shown in Fig. 2. The level of TG increased significantly $(\mathrm{p}<0.001)$ when the daily diet was replaced with the basal diet.

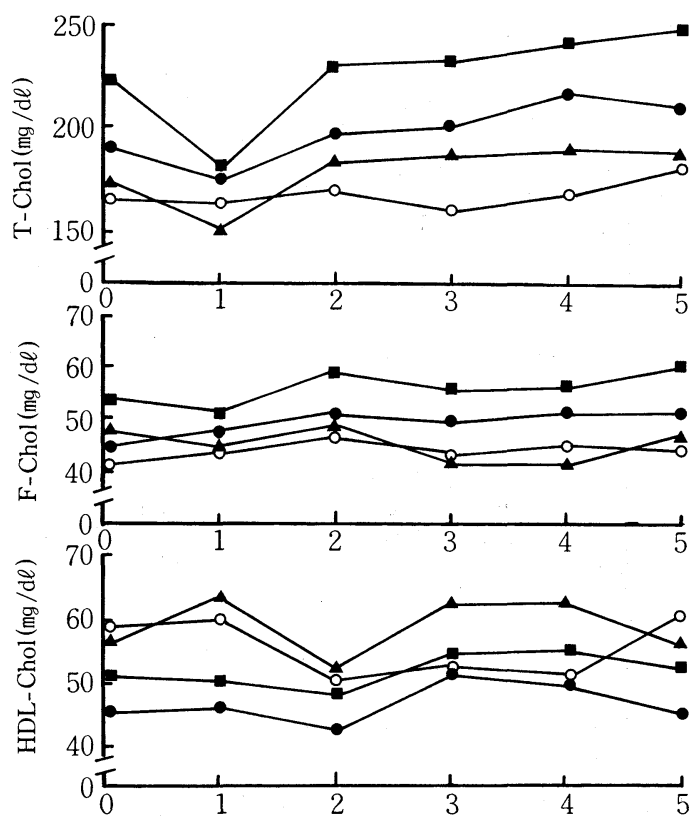

Fig. 1 Variations of Serum Total-, Freeand High Density Lipoprotein Cholesterol.

- : Subject A, $\bigcirc$ : Subject B,

A: Subject C, $\mathbf{\square}$ : Subject D.

0-1: Intake the Basal Diet.

1-4: Intake Lentinus Edodes Diets. Supplemental Level $; 1-2: 20 \mathrm{~g}$, $2-3: 40 \mathrm{~g}, 3-4: 60 \mathrm{~g}$.

$4-5$ : Intake the Daily Diet.

It decreased by addition of lentinus edodes compared with the level in the case of the basal diet. Variation of PL was hardly observed, and throughout the experimental period, nearly the same level was maintained.

Correlation between serum lipids and dietary factors is shown in Table 5. Between T-chol, F-chol, $\mathrm{PL}$ and dietary factors, no significant correlation was observed. HDL-chol was directly proportional to carbohydrate-fat ratio significantly $(\mathrm{p}<0.02)$, and was inversely proportional to fat intake, fat-protein ratio and carbohydrate-protein ratio significantly $(p<0.05)$, respectively. TG was inversely proportional only to protein intake significantly $(\mathrm{p}<0.05)$.

\section{DISCUSSION}

Although the diet of Japanese has been changed to the westernized pattern, life style of diet in rural 

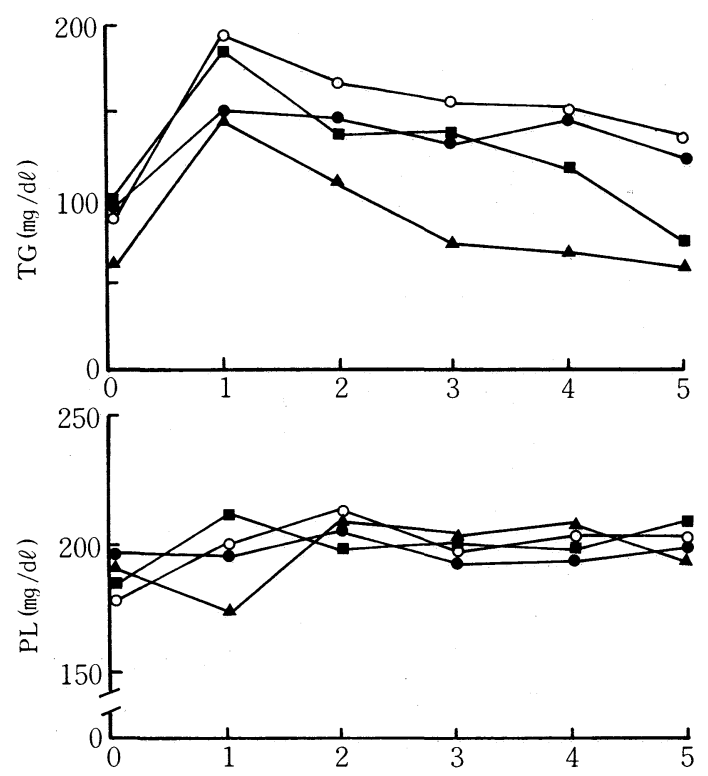

Fig. 2 Variations of Serum Triglycerides and Phospholipids.

: Subject A, $\bigcirc$ : Subject B,

$\boldsymbol{\Delta}$ : Subject C, $\mathbf{\square}$ : Subject D.

0-1 : Intake the Basal Diet.

1-4 : Intake Lentinus Edodes Diet. Supplemental Level; $1-2: 20 \mathrm{~g}$, $2-3: 40 \mathrm{~g}, 3-4: 60 \mathrm{~g}$.

4-5: Intake the Daily Diet.

areas has remained its own characteristics. Lentinus edodes intake is one of characteristics of diet in rural areas.

As to relationship between mortality from atherosclerosis and diets, a report of Yerushalmy et $\mathrm{al}^{10)}$ is available. According to that report, it is directly proportional to total energy $(r=+0.723)$, energy from fat $(r=+0.659)$, animal fat $(r=+0.684)$, protein $(\mathrm{r}=+0.709)$, animal protein $(\mathrm{r}=+0.759)$ and carbohydrate $(r=+0.305)$, and inversely proportional to energy from vegetable fat $(r=-0.236)$ and vegetable protein $(r=-0.430)$.

Tokita et $\mathrm{al}^{2}$ reported about the effect of lentinus edodes on serum lipids that by intake of lentinus edodes cholesterol in decreased by an effective substance called eritadenine. Kimoto et $\mathrm{al}^{3)}$ reported that lentinus edodes decreased T-chol, F-chol and PL. Suzuki et $\mathrm{a}^{5)}$ carried an experiment using man in which cholesterol decreasing effect of lentinus edodes was recognized. However, nothing
Table 5. Correlation between Serum Lipids and Nutrition Intake.

\begin{tabular}{lcccccc}
\hline & $\mathrm{P}$ & $\mathrm{F}$ & $\mathrm{C}$ & $\mathrm{F}-\mathrm{P}$ & $\mathrm{C}-\mathrm{F}$ & $\mathrm{C}-\mathrm{P}$ \\
\hline $\begin{array}{l}\text { T- } \\
\text { chol. }\end{array}$ & +0.454 & +0.169 & +0.185 & -0.008 & -0.129 & -0.071 \\
$\begin{array}{l}\text { F- } \\
\text { chol. }\end{array}$ & +0.058 & +0.144 & +0.107 & +0.097 & -0.230 & +0.053 \\
$\begin{array}{l}\text { HDL- } \\
\text { chol. }\end{array}$ & +0.102 & $-0.532^{*}$ & -0.477 & $-0.546^{*}$ & +0.605 & -0.497 \\
T G & $-0.535^{*}$ & +0.091 & -0.024 & +0.255 & -0.363 & +0.239 \\
P L & +0.117 & -0.083 & -0.082 & -0.108 & +0.083 & -0.131 \\
\hline
\end{tabular}

Significant level: ${ }^{*} \mathrm{p}<0.05,{ }^{* *} \mathrm{p}<0.02$, $\mathrm{P}$ : Protein, F : Fat, C : Carbohydrate.

is stated about components of diet, thus a doubt remains therein whether it was really the effect of lentinus edodes itself. In this study the reason why no significant effect was given to serum lipids in spite of fairly high level of lentinus edodes intake is considered to be because of a composition of basal diet. Compared with the daily diet, the basal diet is low in protein and high in carbohydrate. Olson et $\mathrm{al}^{11)}$ reported that cholesterol is decreased by intake of low protein diet. We also have obtained the result that $\mathrm{T}$-chol is decreased by intake of basal diet. Furthermore, Goto et $\mathrm{al}^{12)}$ reported on an increase of TG upon intake of high carbohydrate diet. We also gained the result of a significant increase $(\mathrm{p}<$ 0.01 ) upon intake of basal diet. In case when lentinus edodes is added to a diet which increases cholesterol, such increase might be controlled or decreased, however, it seems to be rather difficult to expect such control of increasing or decreasing effect, when lentinus edodes is added to the basal diet with the composition an stated above. As to TG, similar to the report of Kimoto et $\mathrm{al}^{3}$. No significant effect was found upon intake of lentinus edodes, and even at fairly high level of addition nearly all of the subjects indicated $110 \mathrm{mg} / \mathrm{dl}$ or over. It is apparent that HDL-chol has an antiatherogenic action. Williams et $\mathrm{al}^{13)}$ report that it is directly proportional to activity and alcohol consumption, and inversely proportional to cigarette smoking and obesity. In this study HDL-chol was directly proportional to carbohydrate-fat ratio significantly $(\mathrm{p}<0.02)$, and inversely proportional to 
fat intake, fat-protein ratio and carbohydrateprotein ratio, respectively at a significance of $p<0$. 05 . These results were nearly corresponded with the report of Hjermann et $\mathrm{al}^{14}$. The reason why $\mathrm{TG}$ is inversely proportional to protein intake significantly $(\mathrm{p}<0.05)$ and when the low protein diet was intaken, TG increase, is considered to be because of TG management disorder and endogeneous TG synthesis acceleration. As to effect of the dietary factor on serum lipids, it is assumed that a single nutrient dose not react directly, but plural factors are closely related with each other. As these which give effect on serum lipids, there are numerous factors such as activity, cigarette smoking, etc., in addition to the dietary factor, that are also to be studied further.

\section{CONCLUSION}

In the present investigation, the variation of human serum lipids by lentinus edodes intake were examined.

Serum lipids showed no significant change by intaking of lentinus edodes. HDL-chol was directly proportional to carbohydrate-fat ratio significantly $(\mathrm{p}<0.02)$, and was inversely proportional to fat intake, fat-protein ratio and carbohydrate-protein ratio significantly $(\mathrm{p}<0.05)$, respectively. TG was inversely proportional only to protein intake significantly $(\mathrm{p}<0.05)$.

\section{REFERENCES}

1) Goto, Y.: Hyperlipemia and Atherosclerosis. J. Jpn. Atheroscler. Soc. $5: 1-15,1977$

2) Tokita, F., Shibukawa, N., Yasumoto, T. and Kaneda, T. : Effect of Mushrooms on Cholesterol Metabolism in
Rats (VI). Separation and Chemical Structure of the Plasma Cholesterol Reducing Substance from Mushroom. J. Jpn. Soc. Food and Nutr. 24 : 92-95, 1971

3 ) Kimoto, M., Yoshizawa, S., Ochi, H., Ohmura, T. and Michi, K.: Effect of "Shiitake" Feeding on the Lipid Components of Plasma and Liver of Albino Rats. J. Jpn. Soc. Food and Nutr. 29 : 275-281, 1976

4) Amano, M., Miyake, Y. and Ito, T.: The Effect of Shiitake on the Composition of Fatty Acid in Plasma and Liver Lipids. J. Jpn. Soc. Food and Nutr. 24 : 428-433, 1971

5 ) Suzuki, S., Oshima, S. and Tsuji, K.: Influence of Cotrinellus Shiitake on Human Serum Cholesterol. J. Jpn. Soc. Food and Nutr. 25 : 130-131, 1967

6) Zurkowski, P. : A Rapid Method for Cholesterol Determination with a Single Reagent. Clin. Chem. 10:451-453, 1964

7) Sakurabayashi, I. : HDL Cholesterol. Rinsho Kensa. 23 : 121-127, 1979

8) Fletcher, M. J. : A Colorimetric Method for Estimating Serum Triglycerides. Cli. Chem. Acta. 22 : 385-392, 1968

9) Kushiro, H. and Fukui, I. : Measurement of Phospholipids in Blood Serum-Hoelfmayr-Fried Method. Rinsho Byori. $15: 853-856,1967$

10) Yerushalmy, J. and Hilleboe, H. E. : Fat in the Diet and Mortality from Heart Disease. New York State J. Med. 57 : 2343-2354, 1957

11) Olson, R. E., Vester, J. W., Gursey, D., Davis, N. and Longman, D.: The Effect of Low Protein Diet upon Serum Cholesterol in Man. Am. J. Clin. Nutr. $6: 310-324$, 1958

12) Goto, Y., Nakamura, H., Hori, S. and Goto, M. : Difference in the Effects of Sucrose and Starch on the Plasma Lipids. Nippon Ronen Igakukai Zasshi. 3 : 295-299, 1966

13) Williams, P., Robinson, D. and Bailey, A. : High Density Lipoprotein and Coronary Risk Factors in Normal Men. The Lancet $8107: 72-75,1979$

14) Hjermann, I., Sven, C. E., Helgeland, A., Holme, I., Leren, P. and Trygg, K. : The Effect of Dietary Changes on High Density Lipoprotein Cholesterol. Am. J. Med. 66 : 105-109, 1979 


\section{農村地域に括ける健康保持を指向したシイタケ摂取による}

人血清脂質レベルの変動に関する研究

中村武夫*, 三好 保 ${ }^{2 *}$, 今木雅英 ${ }^{2 *}$, 山田勇樹 $2 *$, 吉村 武 $2 *$

農村地域における健康保持を目的として, シイタケ摂取による人血清脂質レベルの変動について 検討した。

基礎食にシイタケを 20,40 よび $60 \mathrm{~g}$ 付加した食事を打の扮の 5 日間摂取させたが, 血清脂質レべ ルの有意な変動は認められなかった。

実験食中の栄養摂取量と各血清脂質レベルとの相関性について検討した結果, HDL-コレステ ロール量が炭水化物一脂肪比と有意 $(\mathrm{p}<0.02)$ な正相関を, 脂肪摂取量, 脂肪一蛋白質比および炭 水化物一蛋白質比と扔の扔の有意 $(\mathrm{p}<0.05)$ な負相関を認めた。またトリグリセライド量と蛋白質 摄取量との間に有意 $(\mathrm{p}<0.05)$ な負相関を認めた。

血清コレステロールレベルが正常範囲にある健康な青年に括いては, シイタケ摂取による血清コ レステロールレベルの減少は認められなかった。

* 近畿大学薬学部

$2 *$ 徳島大学医学部公衆衛生学教室

（受付：1987年 2 月16日） 